\title{
Rancang Bangun Antena Mikrostrip Triangular Patch Planar Array 2x2 Elemen Frekuensi 1,2 GHz untuk Penerima Video Wireless LCD Projector
}

\author{
Muhammad Nur Tri Yuliarto $^{1}$, Agus Wagyana ${ }^{2}$ \\ 1,2 Program Studi D3 Telekomunikasi, Jurusan Teknik Elektro, Politeknik Negeri Jakarta \\ Jl. Prof. Dr. G.A Siwabessy, Kampus UI Depok 16425 \\ Email:mnurtriy@gmail.com
}

\begin{abstract}
Abstrak
LCD Projector banyak digunakan untuk menunjang presentasi pada kegiatan belajar mengajar, rapat, seminar dan lain sebagainya. Penelitian ini membahas perancangan dan pembuatan antena mikrostrip triangular patch planar array $2 \times 2$ elemen sebagai antena penerima video wireless LCD Proyektor untuk mengatasi keterbatasan panjang kabel. Metode penelitian dimulai dari perancangan, simulasi hasil rancangan, fabrikasi, pengukuran parameter serta pengujian antena. Perancangan dilakukan menggunakan aplikasi CST Studio Suite, kemudian dibuat pada PCB FR-4. Pengujian meliputi pengukuran parameter dan kinerja antena. Pada pengukuran parameter antena diperoleh nilai sesuai dengan spesifikasi yang telah ditentukan, yakni gain di atas $3 \mathrm{~dB}$, VSWR di bawah $2 \mathrm{~dB}$, Return Loss di bawah $-10 \mathrm{~dB}$ dan pola radiasi unidirectional. Hasil pengujian kinerja antena menunjukkan bahwa kualitas penerimaan sinyal dan kulaitas video dari antena penerima mikrostrip yang dibuat masih lebih baik dibandingkan antena bawaan perangkat penerima.
\end{abstract}

Kata kunci: Antena mikrostrip triangular patch plannar array 2x2 elements, wireless LCD projector

\begin{abstract}
LCD projectors are widely used to support presentations on teaching and learning activities, meetings, seminars and so on. This study discusses the design and manufacture of a $2 \times 2$ planar array triangular patch microstrip antenna as a receiving antenna for wireless $L C D$ projectors to overcome cable length limitations. The research method starts from the design, simulation of design results, fabrication, parameter measurement and antenna testing. The design was carried out using the CST Studio Suite application, then made on the FR-4 PCB. Testing includes measurement of antenna parameters and performance. In testing the antenna parameters, the values obtained are in accordance with predetermined specifications, gain above $3 d B$, VSWR below $2 d B$, return loss below $-10 \mathrm{~dB}$ and unidirectional radiation pattern. The antenna performance test results show that the quality of signal and video reception from the microstrip receiving antenna that has been made is still better than the default antenna for the receiver device.
\end{abstract}

Keywords: Microstrip triangular patch plannar $2 \times 2$ elements, wireless LCD projector

\section{Pendahuluan}

Liquid Crystal Display (LCD) Projector merupakan salah satu jenis proyektor yang digunakan untuk menampilkan video, gambar, atau data dari komputer pada sebuah layar atau permukaan datar seperti tembok dan sebagainya. LCD Projector pada saat ini dimanfaatkan sebagai perangkat bantu untuk melakukan presentasi pada kegiatan belajar mengajar, rapat, seminar, dan lain-lain. Penggunaan perangkat wireless audio video transmitter and receiver pada LCD projector memberikan solusi bagi keterbatasan panjang kabel yang digunakan untuk menghubungkannya dengan komputer. Penelitian ini membahas perancangan dan pembuatan antena penerima mikrostrip pada perangkat wireless av transmitter and receiver yang dapat menggantikan atau meningkatkan jangkauan 
komunikasi antara komputer dan proyektor LCD tersebut.

Perangkat wireless av transmitter and receiver yang digunakan diperlihatkan pada Gambar 1 [1].

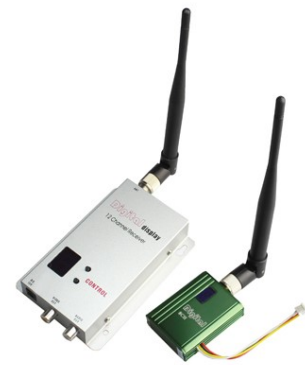

Gambar 1. Perangkat Wireless $A V$ Transmitter and Receiver

Jenis antena bawaan pada perangkat ini adalah antena dipole dengan frekuensi kerja dari $980 \mathrm{MHz}$ sampai dengan 1,360 GHz (12 kanal). Spesifikasi perangkat ini diperlihatkan pada Tabel 1 .

Tabel 1. Spesifikasi Perangkat Wireless A/V Transmitter \& Receiver

\begin{tabular}{ll}
\hline Parameter & Spesifikasi \\
\hline Tegangan kerja & $12 \mathrm{VDC}$ \\
Arus kerja & $250 \mathrm{~mA}$ \\
Frekuensi output & $980 \mathrm{MHz}, 1,010 \mathrm{GHz}, 1,040 \mathrm{GHz}, 1,08$ \\
& $\mathrm{GHz} / 1,120 \mathrm{GHz} / 1,160 \mathrm{GHz} / 1,200$ \\
& $\mathrm{GHz} / 1,240 \mathrm{GHz} / 1,280 \mathrm{GHz} / 1,320$ \\
& $\mathrm{GHz} / 1,360 \mathrm{GHz}$ \\
Jumlah kanal & 12 \\
Daya output & $400 \mathrm{~mW}$ \\
Antena & Dipole \\
Tegangan output & $1 \mathrm{Vp}-\mathrm{p}$ \\
Audio output & $1 \mathrm{Vp}-\mathrm{p}$ \\
\hline
\end{tabular}

\section{Parameter Antena}

Pola radiasi (radiation pattern) antena adalah gambaran sifat radiasi, pancaran, maupun penerimaan sinyal pada medan jauh sebagai fungsi arah atau sudut. Pola radiasi digambarkan dengan koordinat polar main lobe dan minor lobe. Pola radiasi dapat disebut sebagai pola medan (field pattern) apabila intensitas radiasi yang digambarkan adalah kuat medannya dan disebut pola daya (power pattern) apabila intensitas radiasi adalah vektor pointing-nya. Beberapa jenis pola radiasi antena adalah unirectional, bidirectional dan omnidirectional

Gain adalah perbandingan daya pancar suatu antena terhadap antena referensi atau pertambahan daya yang diradiasikan pada arah tertentu dari suatu antena dibandingkan dengan daya yang diradiasikan pada arah yang sama oleh suatu antena acuan [2].
Bandwidth antena merupakan kisaran frekuensi dimana antena dapat beroperasi dengan kinerja yang baik sesuai spesifikasi yang ditetapkan. Spesifikasi tersebut meliputi: diagram radiasi, tinggi dari side lobe, gain, polarisasi, impedansi masukan/faktor refleksi [3].

Voltage Standing Wave Ratio (VSWR) adalah tingkat ketidaksesuaian antara beban dan saluran pada antena. Nilai VSWR didapatkan dengan melakukan perbandingan antara amplitudo gelombang berdiri (standing wave) maksimum dengan minimum. Bila impedansi saluran transmisi tidak sesuai dengan impedansi transmitter atau receiver maka akan timbul daya refleksi pada saluran yang berinterferensi dengan daya maju. Interferensi ini menghasilkan gelombang berdiri yang besarnya bergantung pada besarnya daya refleksi [3].

Return Loss merupakan koefisien refleksi dalam bentuk logaritmik. Return loss menunjukkan daya yang hilang karena antena dan saluran transmisinya tidak matching (tidak sesuai) sehingga tidak semua daya diradiasikan, melainkan ada yang dipantulkan kembali [3].

Half power beam width (HPBW) adalah sudut dari titik-titik pada pola setengah daya dalam main lobe (penurunan $3 \mathrm{~dB}$ dari pancaran maksimum) [4].

\section{Metode Penelitian}

Gambar 2 adalah diagram alir rancang bangun antena ini. Hal pertama yang dilakukan adalah menentukan spesifikasi antena yang diinginkan seperti ditunjukkan pada Tabel 2.

Tabel 2. Spesifikasi Antena yang Diinginkan

\begin{tabular}{ll}
\hline \multicolumn{1}{c}{ Parameter } & \multicolumn{1}{c}{ Nilai } \\
\hline Frekuensi & $1,2 \mathrm{GHz}$ \\
Return Loss & $<-10 \mathrm{~dB}$ \\
VSWR & $<2$ \\
Pola radiasi & Unidirectional \\
Gain & $>3 \mathrm{~dB}$ \\
\hline
\end{tabular}

Selanjutnya adalah menentukan besar elemen pada antena dengan melakukan perhitungan.

\section{Perhitungan Lebar Saluran Mikrostrip}

Posisi pencatuan harus dipilih sedemikian rupa agar matching antara impedansi konektor luar $50 \Omega$ dengan impedansi masukan dari antena mikrostrip $50 \Omega$ untuk antena penerima video pada frekuensi 1,2 GHz. Dengan menggunakan saluran transmisi

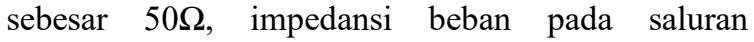
transmisi $Z_{\mathrm{L}}$ adalah $50 \Omega$ dan untuk impedansi saluran $Z_{\mathrm{o}}$ adalah $25 \Omega$ atau setengah dari nilai $\mathrm{Z}_{\mathrm{L}}$. 


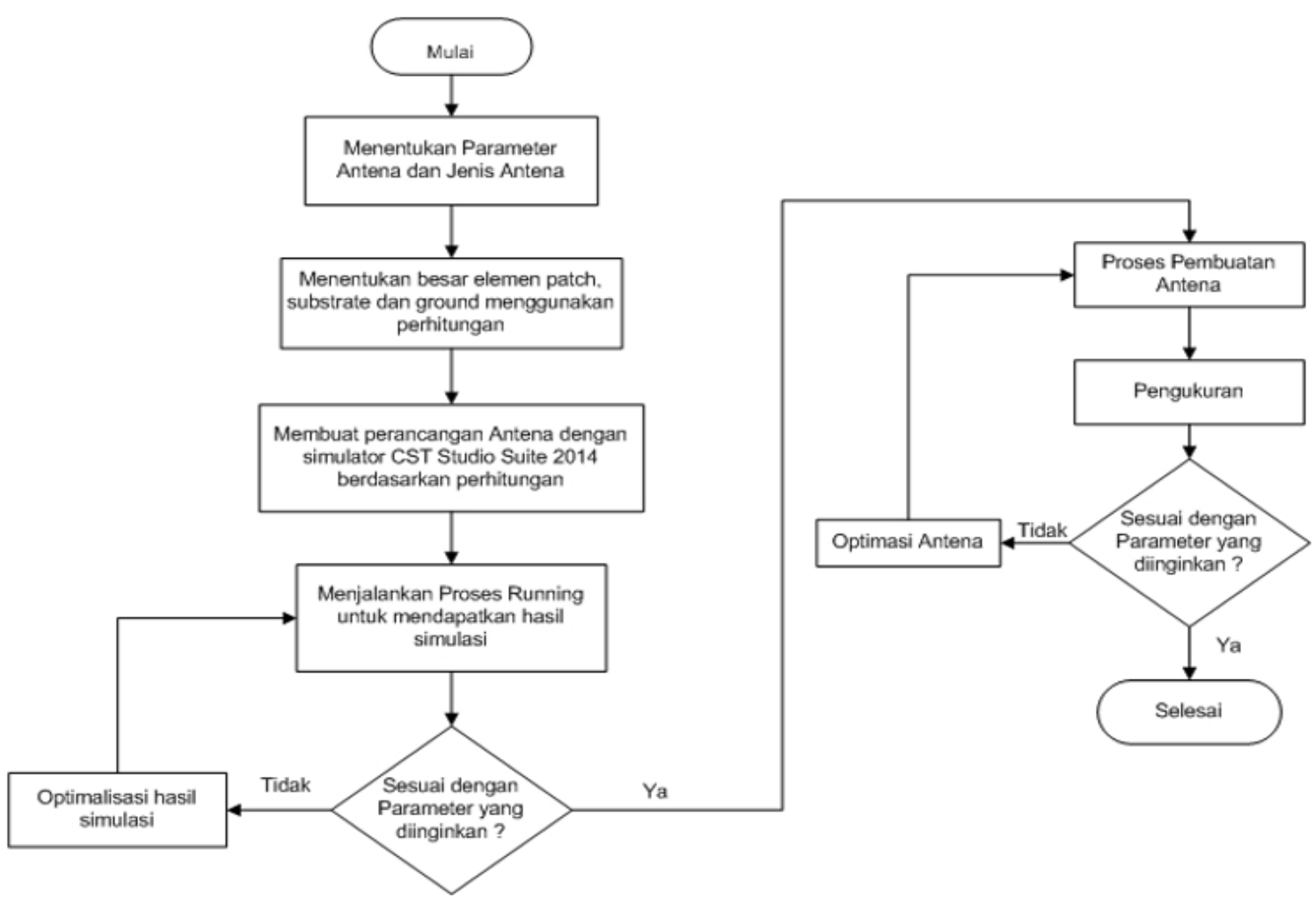

Gambar 2. Flowchart Rancang Bangun Antena

Setelah mengetahui besar impedansi transformer $\mathrm{Z}_{\mathrm{L}}$ dan $Z_{0}$ maka besar transformer $Z_{T}$ bisa dihitung dengan menggunakan persamaan sebagai berikut :

$$
Z_{T}=\sqrt{Z_{L} x Z_{o}}
$$

Penentuan lebar saluran transmisi agar didapat impedansi saluran yang matching dapat dihitung dengan persamaan-persamaan berikut [5]:

$$
\begin{gathered}
A=\frac{z}{60} \sqrt{\frac{\varepsilon r+1}{2}}+\frac{\varepsilon r-1}{\varepsilon r+1}\left(0,23+\frac{0,11}{\varepsilon r}\right) \\
\frac{W Z}{d}=\frac{8 e^{A}}{e^{A-2}}
\end{gathered}
$$

dimana:

$\mathrm{Z}=$ impedansi saluran, beban, atau transformer $\left(Z_{0}\right.$, $\mathrm{Z}_{\mathrm{L}}$, atau $\mathrm{Z}_{\mathrm{T}}$ )

$\varepsilon_{\mathrm{r}}=$ permitivitas dielektrik relatif substrat

$\mathrm{W}=$ lebar saluran transmisi

$\mathrm{d}=$ lebar spasi antar elemen

\section{Perhitungan Antena Mikrostrip Triangular Patch}

Untuk dapat melakukan pembuatan Antena Mikrostrip Triangular Patch maka dilakukan perhitungan untuk menentukan besar patch segitiga yang akan digunakan. Untuk mengetahui panjang sisi segitiga menggunakan persamaan berikut:

$$
a=\frac{2 c}{3 f_{r} \sqrt{\varepsilon_{r}}}
$$

dimana :

$\mathrm{a}=$ panjang sisi segitiga

$\mathrm{f}_{\mathrm{r}}=$ frekuensi kerja

$\varepsilon_{r}=$ permitivitas dielektrik relatif substrat

$\mathrm{c}=$ kecepatan cahaya $3 \times 10^{8} \mathrm{~m} / \mathrm{s}$

Kemudian dalam membuat patch segitiga pada software simulator (CST Studio Suite) digunakan menu cylinder maka harus dicari terlebih dahulu jarijari dari sisi segitiga dengan menggunakan rumus jari-jari segitiga dalam lingkaran berikut:

$$
r=\frac{a}{\sqrt{3}}
$$

dimana :

$\mathrm{a}=$ panjang sisi segitiga

$\mathrm{r}=$ jari - jari segitiga 
Selanjutnya untuk menghitung spasi antar patch-nya digunakan persamaan:

$$
d=\frac{\lambda}{2}=\frac{C}{2 f}
$$

dimana :

$\lambda=$ panjang gelompang

$\mathrm{c}=$ kecepatan cahaya $\left(3 \times 10^{8} \mathrm{~m} / \mathrm{s}\right)$

$\mathrm{f}=$ frekuensi gelombang

\section{Set Up Alat}

Gambar 3 menunjukkan set up dari rangkaian sistem pengiriman video secara wireless dari laptop ke antena pemancar dan diterima oleh antena penerima untuk ditampilkan pada proyektor LCD.

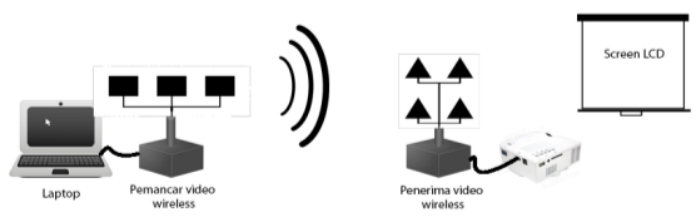

Gambar 3. Set Up Rangkaian Alat

\section{Model Rancangan Antena Mikrostrip Triangular Patch Planar Array 2x2 Elemen}

Gambar 4 adalah model perancangan dari Antena Mikrostrip Triangular Patch Planar Array 2x2 Elemen.

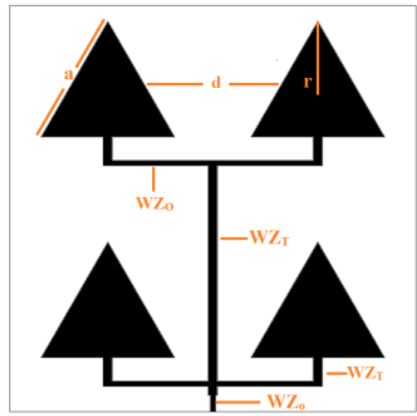

Gambar 4. Pemodelan Antena Mikrostrip Triangular Patch Planar Array 2x2 Elemen

\section{Hasil dan Pembahasan}

Berikut ini akan dibahas tentang hasil-hasil perancangan, simulasi dan pengujian antena.

\section{Hasil Perancangan Lebar Saluran Transmisi}

Hasil perhitungan lebar saluran dengan menggunakan persamaan (2) dan (3) diperoleh nilainilai lebar saluran seperti yang diperlihatkan pada Gambar 5.

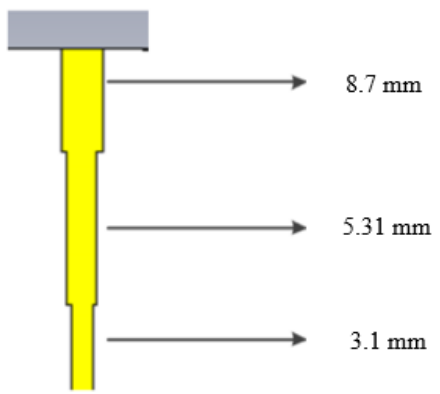

Gambar 5. Desain Lebar Saluran Transmisi

\section{Hasil Perancangan Patch Antena}

Berdasarkan perhitungan yang telah dilakukan, didapatkan nilai-nilai parameter untuk membuat patch triangular, yaitu sisi segitiga $a=80,36 \mathrm{~mm}$, jari-jari segitiga $r=46,40 \mathrm{~mm}$, dan lebar spasi antar elemen sebesar $\mathrm{d}=125 \mathrm{~mm}$.

\section{Proses Simulasi}

Gambar 6 adalah tampilan dari simulasi perancangan dari Antena Mikrostrip Triangular Patch Planar Array 2x2 Elemen sesuai dengan perhitungan yang dilakukan.

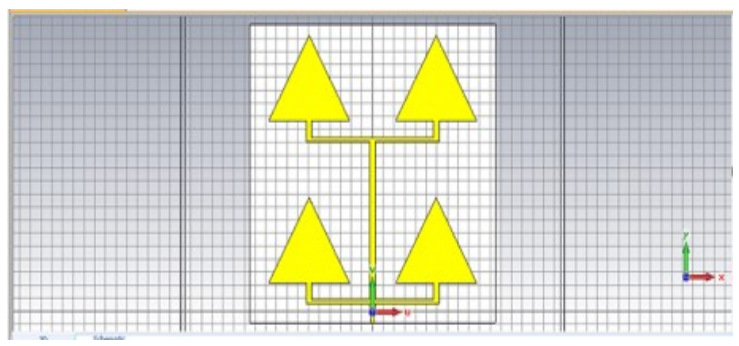

Gambar 6. Rancangan Simulasi Antena

Dari proses simulasi didapatkan hasil yang belum sesuai dengan spesifikasi yang diinginkan. Oleh karena itu diperlukan optimasi hasil simulasi antena.

Gambar 7 menunjukkan pengurangan nilai parameter untuk jari-jari segitiga dimana nilai sebelumnya sebesar $\mathrm{r}=46,40 \mathrm{~mm}$ lalu dikurangi $2.6593 \mathrm{~mm}$ sehingga menjadi $\mathrm{r}=43.7407 \mathrm{~mm}$. Nilai $2.6593 \mathrm{~mm}$ merupakan hasil terbaik setelah beberápa kali dilakukan percobaan. 


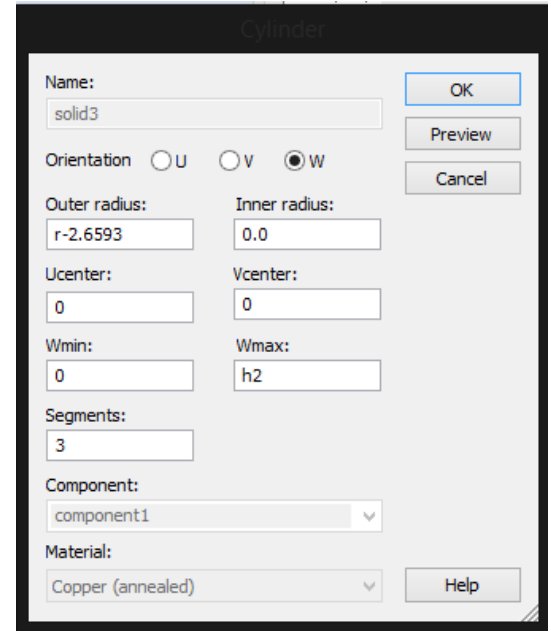

Gambar 7. Optimasi Parameter Patch

Setelah dilakukan optimasi maka didapatkan perbandingan nilai setelah optimasi dengan hasil simulasi awal seperti diperlihatkan pada Tabel 3.

Tabel 3. Hasil Simulasi Sebelum dan Setelah Optimasi

\begin{tabular}{lll}
\hline Parameter & Sebelum & Setelah \\
\hline Return Loss $(\mathrm{dB})$ & $-6,8084429$ & -20.826586 \\
VSWR & 2.6808315 & 1.2000321 \\
Gain $(\mathrm{dB})$ & $6,28 \mathrm{~dB}$ & $6.28 \mathrm{~dB}$ \\
Pola radiasi & Unidirectional & Unidirectional
\end{tabular}

\section{Hasil Pengujian Parameter Antena}

Hasil dari perancangan antena mikrostrip tersebut kemudian akan dibandingkan dengan hasil pengujian sesungguhnya, yang meliputi return loss, VSWR, Gain dan Pola Radiasi.

\section{Return Loss}

Gambar 8 memperlihatkan grafik perbandingan antara return loss antena hasil simulasi dengan hasil pengukuran.

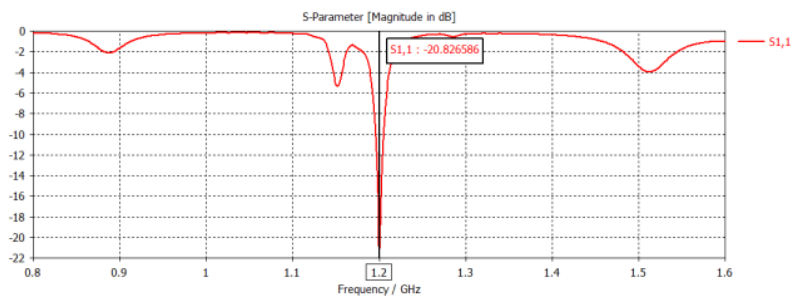

(a)

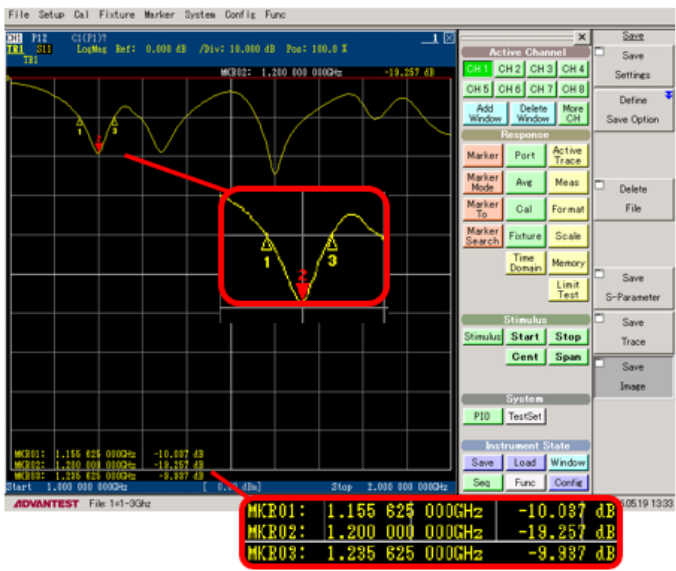

(b)

Gambar 8. Perbandingan Return Loss Hasil Simulasi dengan Hasil Pengukuran Antena Mikrostrip : (a) Simulasi, (b) Pengukuran

Pada hasil simulasi nilai return loss yang didapat adalah (a) -20.826586 dB pada frekuensi $1.2 \mathrm{GHz}$ sedangkan return loss yang didapatkan dari hasil pengukuran adalah (b) $-19.257 \mathrm{~dB}$ pada frekuensi 1.2 GHz. Perbedaan yang terjadi pada nilai return loss ini, diakibatkan karena proses simulasi merupakan proses uji ukur virtual yang dilakukan pada ruang ideal dengan nilai-nilai bahan pembentuk antena yang presisi. Sedangkan proses pengukuran adalah proses nyata yang dilakukan di ruang yang memungkinkan adanya sinyal pantul yang dihasilkan benda-benda dalam ruangan tersebut.

\section{VSWR}

Gambar 9 memperlihatkan grafik perbandingan antara VSWR antena hasil simulasi dengan hasil pengukuran.

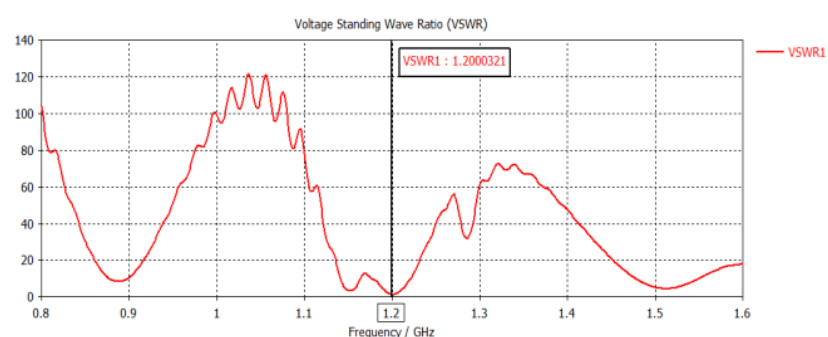

(a) 


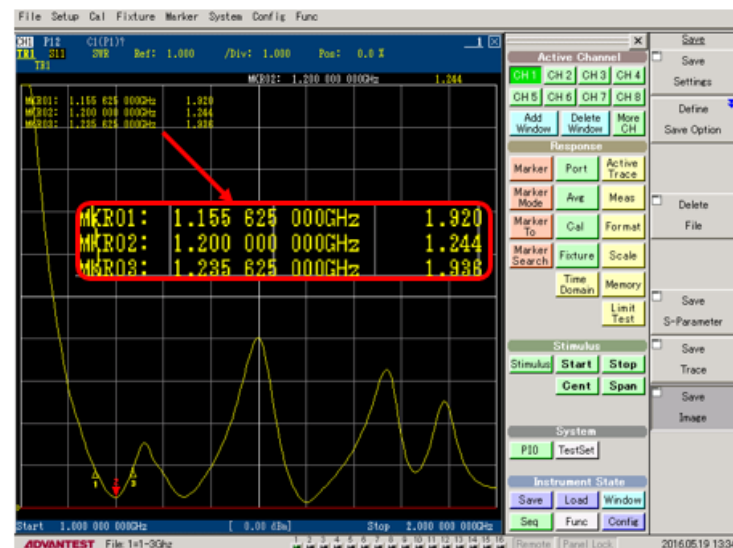

(b)

Gambar 9. Perbandingan VSWR Hasil Simulasi dengan Hasil Pengukuran Antena Mikrostrip : (a) Simulasi, (b) Pengukuran

VSWR yang didapatkan pada frekuensi tengah 1,2 $\mathrm{GHz}$ saat simulasi adalah 1.2000321, sedangkan VSWR yang didapatkan pada frekuensi tengah 1,2 $\mathrm{GHz}$ saat pengukuran adalah 1.244493. Perbedaan nilai VSWR ini berhubungan dengan perbedaan yang terjadi pada nilai return loss. Karena apabila nilai return loss yang didapatkan semakin kecil maka nilai VSWR akan semakin mendekati nilai idealnya, yakni 1 walaupun dalam hal ini sangat sulit untuk mendapatkan VSWR dengan nilai tersebut. Nilai VSWR yang didapatkan pada hasil pengukuran lebih kecil dibandingkan dari nilai yang didapat pada saat melakukan simulasi, namun hal ini tidak membuat antena disebut gagal, karena nilai VSWR yang didapat pada saat pengukuran masih berada dalam spesifikasi awal yang ditentukan, yakni sebesar $<2$. Perbedaan nilai ini dapat terjadi karena kondisi sekitar yang tidak ideal seperti melakukan simulasi yang prosesnya terjadi di ruang ideal dengan material yang presisi.

\section{Pola Radiasi}

Dari hasil pengukuran pola radiasi Antena Mikrostrip Triangular Patch Planar Array 2x2 Elemen dapat terlihat bentuk pola radiasi. Gambar 10 memperlihatkan plot perbandingan pola radiasi antena hasil simulasi dengan pengukuran.

Pada Gambar 10 (a) dan (b) dapat dilihat hasil dari pengukuran pola radiasi pada hasil simulasi dan hasil pengukuran. Kedua hasil pola radiasi memiliki bentuk yang tidak jauh berbeda. Pada gambar dapat dilihat bahwa bentuk pola radiasi dari antena mikrostrip yang dibuat adalah unidirectional. Dari pengukuran pola radiasi antena, bentuk dari pola radiasi Antena Mikrostrip Triangular Patch Planar Array 2x2 Elemen adalah Unidirectional. Bila dibandingkan dengan hasil pola radiasi dari simulasi dapat dilihat bahwa hasil yang didapat sedikit memiliki kemiripan bentuk dengan hasil pengujian yang dilakukan. Hasil simulasi dan hasil pengujian sama-sama memiliki bentuk unidirectional seperti spesifikasi yang diinginkan.

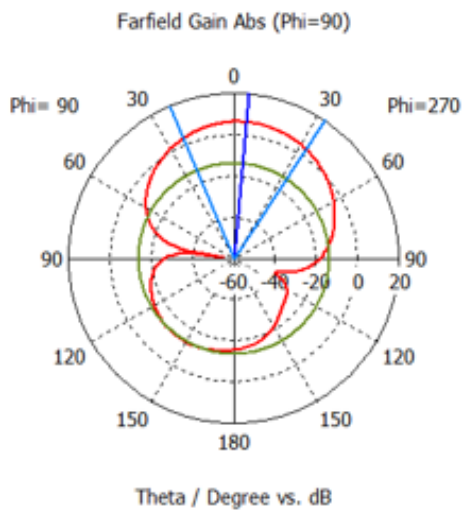

(a)

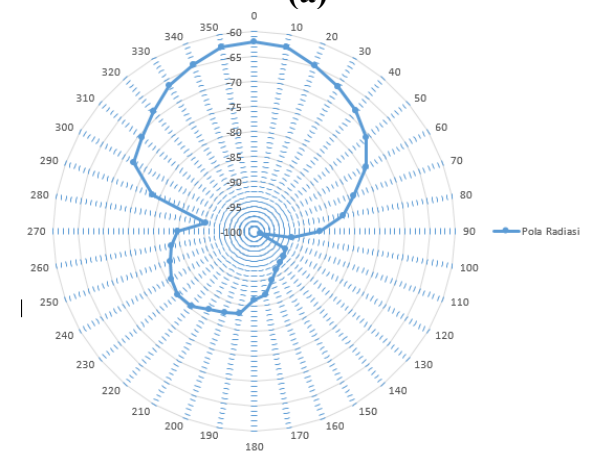

(b)

Gambar 10. Perbandingan Hasil Pengukuran Pola Radiasi : (a) simulasi (b) pengukuran

\section{Half Power Beamwidth}

Setelah mengetahui bentuk dari pola radiasi antena mikrostrip yang dibuat, maka dapat diketahui besar Half Power Beamwidth (HPBW). Untuk mengetahui HPBW antena, harus diketahui terlebih dahulu nilai level sinyal terbesar dari hasil pengukuran pola radiasi antena. Level sinyal terbesar dari antena mikrostrip ini adalah sebesar $-61,96 \mathrm{~dB}$. Untuk mencari nilai HPBW, level sinyal tersebut dikurangi setengah daya atau $-3 \mathrm{~dB}$ maka didapatkan nilai sebesar -58,96 dB. Gambar 11 menunjukan HPBW dari hasil pengukuran pola radiasi yang telah dilakukan.

Pada Gambar 11 dapat dilihat bahwa titik turun $3 \mathrm{~dB}$ dari daya pancar maksimum berada pada sekitar $15^{\circ}$ dan $345^{\circ}$ sehingga dapat diketahui besar HPBW dari pengujian pola radiasi adalah $30^{\circ}$. Perbedaan pengukuran pola radiasi hasil antara hasil simulasi dan pengukuran dapat terjadi akibat kondisi sekitar ruangan pengukuran. 


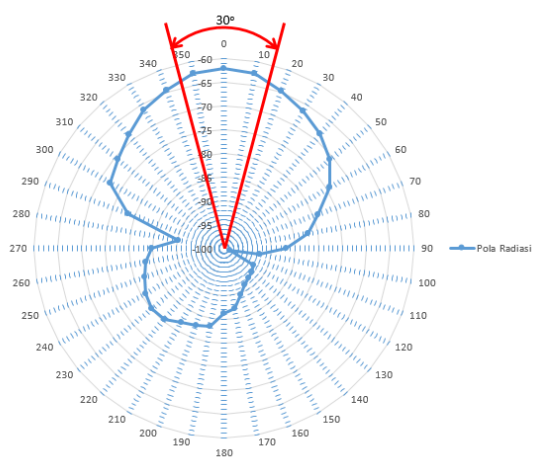

Gambar 11. HPBW Antena Mikrostrip Triangular Patch Planar Array 2x2 Elemen

\section{Gain}

Hasil dari pengukuran gain dari Antena Mikrostrip Triangular Patch Planar Array 2×2 Elemen adalah $10.4 \mathrm{~dB}$, sedangkan pada simulasi bernilai $6,28 \mathrm{~dB}$. Hasil dari pengukuran melebihi spesifikasi yang telah direncanakan sebelumnya, yaitu $>3 \mathrm{~dB}$, sehingga antena mampu bekerja baik dengan gain sebesar 10.4 $\mathrm{dB}$ pada frekuensi kerja 1,2 GHz. Adapun perbedaan antara hasil simulasi dan pengukuran dapat diakibatkan oleh tidak terhitungnya rugi-rugi yang disebabkan pada saat pengukuran gain antena, seperti cable loss dan path loss.

\section{Hasil Pengujian Antena Sebagai Penerima Video Wireless LCD Projector}

Pengujian ini dilakukan untuk mengetahui level sinyal dan kualitas gambar pada saat antena digunakan sebagai penerima video wireless projector.

\section{Level Sinyal}

Pengujian level sinyal dilakukan untuk mengetahui perbandingan nilai level sinyal yang diterima antena dipole dan Antena Mikrostrip Triangular patch Planar Array 2x2 Elemen. Hasil pengujiannya dapat dilihat pada Gambar 12 dimana level sinyal yang diterima oleh Antena Mikrostrip Triangular Patch Planar Array 2x2 Elemen dan Antena dipole mengalami penurunan level sinyal saat jarak antara pemancar dan penerima semakin jauh. Kemudian nilai dari level sinyal yang diterima oleh antena dipole lebih kecil dibandingkan dengan level sinyal milik Antena Mikrostrip Triangular Patch Planar Array 2x2 Elemen pada saat melakukan penerimaan. Pada jarak $5 \mathrm{~m}$ level sinyal yang diterima oleh antena dipole adalah sebesar $-34.5 \mathrm{dBm}$ sedangkan yang diterima oleh Antena Mikrostrip Triangular Patch Planar Array 2x2 Elemen adalah sebesar $-28.4 \mathrm{dBm}$. Kemudian pada jarak terjauh yakni $200 \mathrm{~m}$ antena dipole menerima level sinyal sebesar $-72.0 \mathrm{dBm}$ sedangkan Antena Mikrostrip Triangular Patch Planar Array 2x2 Elemen memiliki level sinyal sebesar $-69.0 \mathrm{dBm}$. Dari hasil tersebut dapat dilihat bahwa nilai level sinyal yang dimiliki antena dipole bawaan perangkat lebih rendah dibandingkan dengan antena mikrostrip hasil rancangan dan dapat dikatakan bahwa Antena Mikrostrip Triangular Patch Planar Array 2x2 Elemen dapat bekerja lebih baik dibandingkan dengan antena dipole milik perangkat.

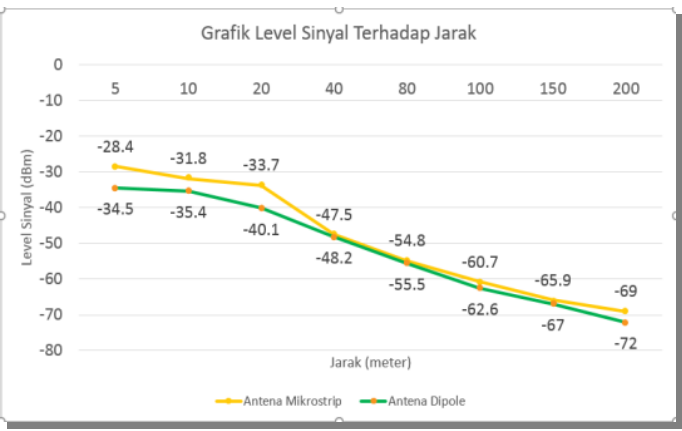

Gambar 12. Grafik Hasil Pengukuran Level Sinyal

\section{Kualitas Gambar}

Untuk memperjelas kinerja Antena Mikrostrip Triangular Patch Planar Array 2x2 Elemen dalam melakukan penerimaan, maka pada pengujian ini akan ditampilkan hasil dari kualitas gambar yang diterima dengan berdasarkan jarak yang berbeda beda dan dibandingkan kualitasnya dengan antena dipole yang merupakan antena bawaan dari perangkat wireless av receiver. Gambar 13 adalah hasil pengujian di dalam ruangan pada jarak $50 \mathrm{~m}$.

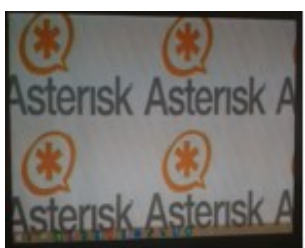

(a)

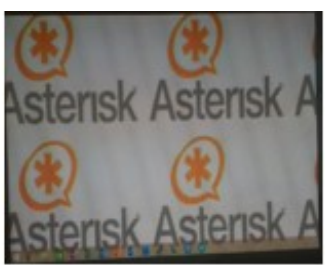

(b)
Gambar 13. Hasil Pengujian Kualitas Gambar pada Jarak 50 meter indoor : (a) Antena Mikrostrip Hasil Rancangan, (b) Antena Dipole

Hasilnya terlihat bahwa kualitas gambar pada jarak 5 $\mathrm{m}$ sampai dengan $50 \mathrm{~m}$ di dalam ruangan masih menunjukkan kualitas gambar dengan parameter "baik". Pada jarak yang lebih jauh, kualitas gambar semakin menurun. Hasil pengukuran pada jarak $150 \mathrm{~m}$ dan 200 m diperlihatkan pada Gambar 14. 


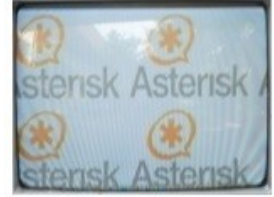

$50 \mathrm{~m}$

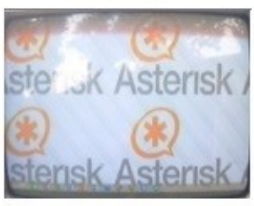

(a)

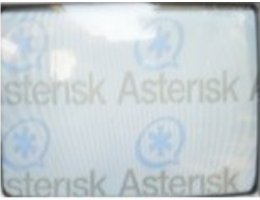

$50 \mathrm{~m}$

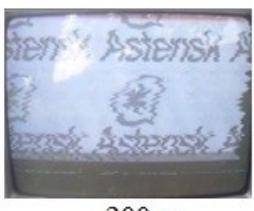

$200 \mathrm{~m}$

(b)

Gambar 14. Hasil Pengujian Kualitas Gambar pada Jarak 150 m dan 200 m Outdoor : (a) Antena Mikrostrip Hasil Rancangan, (b) Antena Dipole

Hasilnya menunjukkan bahwa hasil pengujian dengan antena dipole sudah masuk dalam kategori "buruk" sedangkan antena mikrostrip hasil rancangan masih mampu menampilkan gambar dengan kategori "baik".

\section{Kesimpulan}

Hasil pengujian parameter antena Mikrostrip Triangular Patch Planar Array 2x2 Elemen yang sudah dibuat menunjukkan spesifikasi yang diharapkan, yaitu return loss -19.257, VSWR 1.244 dan gain $10.4 \mathrm{~dB}$. Antena memiliki bentuk pola radiasi unidirectional dan HPBW sebesar $30^{\circ}$. Secara umum, penerimaan sinyal dan kualitas video oleh antena ini lebih baik dibandingkan dengan antena dipole sampai pada jarak $200 \mathrm{~m}$.

\section{Daftar Acuan}

[1] Sunsky, $1.2 \mathrm{GHz} 400 \mathrm{~mW} 8$ Channel Digital Wireless AV transmitter \& receiver, https://www.sunsky-

online.com/product/default!view.do?subject.id= 13085

[2] D. Yandita, Sistem Autotracking Antena Mikrostrip Yagi-Array 3 Elemen menggunakan Aplikasi Android Berbasis Arduino, Politeknik Negeri Jakarta, Depok, 2015.

[3] M. Alaydrus, Antena Prinsip dan Aplikasi, Graha Ilmu, Yogyakarta, 2011.

[4] N. Irwan, B. Dewangga, Rancang Bangun dan Analisis Antena Mikrostrip Rectangular Patch dengan Slot untuk Aplikasi 3G, Universitas Muslim Indonesia, Makassar, 2012.

[5] D.M. Pozar, Microwave Engineering $4^{\text {th }}$ Edition, John Wiley and Son, 2012. 